\title{
The 2005 London Bombings and the Haddon Matrix
}

\section{Jeffrey L. Arnold, MD (Editor)}

On 07 July 2005, terrorists detonated four suicide bombs on the London public transportation system, leading to the largest loss of life from bombings in that city since World War II.

The hazard consisted of four improvised explosive devices (IED), which terrorists, belonging to an Islamic fundamentalist Jihadist network, reportedly crafted from hexamethylene triperoxide diamine (HMTD), a peroxide-based explosive, which can be made from prosaic ingredients like hydrogen peroxide, citric acid, and military heat tablets. ${ }^{1-3}$ Since HMTD degrades at room temperature, the terrorists allegedly preserved it in commercial grade freezers. ${ }^{1}$ The resulting IEDs weighed an estimated $4.5 \mathrm{~kg}$ each and were reportedly packaged in ordinary plastic food containers. 4,5

The event began when four terrorists transported four IEDs to their detonation points in the London public transit system, first in beverage coolers in the back of two automobiles and then in rucksacks on foot. ${ }^{1}$ The terrorists then detonated the IEDs in cars on three different tube trains in tunnels and on the upper level of a double-decker bus, committing suicide in the process. $1,4,6$ The event was sudden onset, short duration, with the three subway IEDs detonated nearly simultaneously by cell phone via alarms set at 08:50 hours (h), followed by the bus IED at 09:47 h. ${ }^{1,4}$ The area of the impact was a swath of London surrounding the four foci: (1) a point on the Circle Line train $100 \mathrm{~m}$ from the Edgware Road station; (2) a point on the Circle Line train $200 \mathrm{~m}$ from the Aldgate station; (3) a point on the Picadilly Line train between the King's Cross and Russell Square station; and (4) at the junction of Woburn Place and Tavistock Square. ${ }^{4,6}$ The population at risk were ordinary London commuters at high crowd density during the peak morning rush hour.

The health damage included more than 700 persons injured, and 56 dead, of which 52 died at the scene. ${ }^{6}$ The types of injuries suffered by the injured survivors ran the gamut of blast injury categories, including tympanic membrane perforations, open wounds, traumatic amputations, burns, and smoke inhalation. ${ }^{6,7}$ Further details of the health damage are likely to be forthcoming in reports in the medical literature.

The health response included bystander, prehospital, and hospital elements. Bystanders played a large role in delivering initial medical care. ${ }^{8,9}$ At the Tavistock Square site, 14 physician bystanders, many attending at a meeting at the nearby British Medical Association, provided on-scene triage and initial medical care. ${ }^{8}$ The London Ambulance Service dispatched 100 ambulances staffed by more than 250 professionals to the four scenes. ${ }^{6}$ Central Ambulance Control also mobilized small groups of physicians to the scenes, who performed pre-assigned roles, including scene management, evacuation, and medical care of individual injured survivors with serious injuries. ${ }^{10}$ Darkness and smoke in the subterranean locations of the three subway sites led to unavoidable delays for many in reaching definitive medical care. ${ }^{10}$ Ultimately, The Royal London Hospital in Whitechapel treated 208 injured survivors, the Royal Free Hospital in Hampstead treated 61, the University College Hospital in Bloomsbury treated 60 patients, and St. Mary's Hospital in Paddington treated 38. $6,10-13$

Some have pointed out that London authorities should have anticipated that such an attack was likely to occur, given the United Kingdom's participation in the US-led coalition that currently occupies Iraq. ${ }^{14}$ Unfortunately, the detonation of home-made IEDs by terrorists belonging to Islamic extremist groups in a Western city against a vulnerable civilian population is nothing new. Nor are the strategies of simultaneous bombings to expand the area of impact, timing an attack during morning rush hour to maximize the number of victims, using suicide to pinpoint a vulnerable population at risk, and detonating an IED within a confined space to leverage the blast energy and generate more health damage. All of these elements have been used elsewhere with similar carnage.

While such an attack may seem intuitively likely to have occurred, it often is easy to point out failures in risk assessment after an event occurs. Risk assessment is a prospective endeavor that integrates evidence and opinion with the goal of accurately predicting and estimating risk in order to provide risk managers with a rational basis for risk reduction. Accordingly, risk assessment depends on accurate, relevant, timely, comprehensive, and comprehensible information as it fine tunes its predictions and estimates.

Nevertheless, the London bombing and its aftermath provide textbook examples of the perils of overestimating and underestimating risk. When risk is overestimated (i.e., Type I error of risk assessment), there may be adverse consequences, such as when people are harmed by measures that are supposed to protect them. A glaring example of this occurred after the London bombings, when a 27 year-old Brazilian electrician was shot and killed by London police who mistook him for a suicide bomber. ${ }^{15}$ When risk is underestimated (i.e., Type II error of risk assessment), there may be adverse consequences as well, such as when people are harmed by a lack of adequate counter-measures. Some would argue that the British government committed a Type II error 
of risk assessment when it failed to predict that simultaneous suicide bombings of the London transportation system would occur. ${ }^{14}$ However in fairness, it also should be noted that in the aftermath of the London bombings, British authorities were able to avert another terrorist attack, thus sparing London from further bloodshed in July 2005.

A core purpose of the World Association for Disaster and Emergency Medicine (WADEM) is to advance the frontier of disaster research in order to shed light on what is unknown in our field. It is clear that the science of disaster medicine urgently needs a tool, which will facilitate a rational, retrospective analysis of risk factors that have contributed to past events and a rational prospective assessment of those that may contribute to future ones.

The WADEM, the Task Force on Quality Control of Disaster Management (TFQCDM), and the Nordic Society for Disaster Medicine have been at the forefront of efforts to develop a common framework for how the disaster medicine and emergency management communities should use the overlapping concepts hazards, events, damage, disasters, and risk in evaluation and research. This framework was published in the first volume of Health Disaster Management Guidelines for Evaluation and Research in the Utstein Style (Guidelines) in 2003. ${ }^{16}$

Of particular importance, the Guidelines proposed a conceptual model of how a disaster occurs, in which a hazard leads to an event, an event leads to health damage, and health damage leads to a health disaster. ${ }^{16}$ As the Guidelines also suggest, some or even all of these components may co-exist in time. For example, in an earthquakerelated disaster, the earthquake fault persists, after-shocks may continue for days, health damage may be ongoing, and the demand for health response may be prolonged.

Next, this conceptual model of how a disaster occurs was married to the definition of risk proffered by the Guidelines (i.e., the objective or subjective probability that something negative will occur) to produce a conceptual model of the risk of a health disaster. ${ }^{16,17}$

According to this model, the risk of a health disaster is really the product of four component risks: (1) the risk that a hazard exists (or will exist within the time frame of the risk assessment); (2) the risk that the hazard will be transformed into an event; (3) the risk that the event will be transformed into some specified health damage; and (4) the risk that the health damage will overwhelm the local community's ability to adequately respond and require external resources (i.e., the risk that the community health response will be inadequate, thereby constituting a health disaster). ${ }^{17}$

The 2005 London bombings also may be divided into these four component risks: (1) the risk that these specific IEDs would be created; (2) the risk that these IEDs would be detonated at a specific time and place against a specific population at risk; (3) the risk that the explosions would cause a specific type and amount of health damage; and (4) the risk that this amount of health damage would overwhelm the ability of the community to adequately respond.

As the astute reader already has noted, the health response in London was adequate and the volume of phys- ical health damage never really amounted to a physical health disaster (although such an analysis does not take into account the mental health sequelae from the attack).

The next step in the maturation of this model of health disaster risk will be to establish a method for analyzing the myriad factors that contribute to the existence of any one of these four component risks. Fortunately, the Haddon matrix, introduced and refined by William Haddon, Jr. in the 1970s, provides an attractive mechanism through which this might be accomplished. ${ }^{18-21}$

As many in the injury prevention community already know, the Haddon matrix is a tool that facilitates the identification and classification of the various factors that contribute to an injury before, during, and after an injury-creating event occurs. These factors are categorized according to whether they relate to the host (victim), agent or vehicle (energy), the physical environment, or the social environment surrounding a given injury. The overall goal of the Haddon matrix is to identify risk factors that may be modified in order to prevent injury.

The application of the Haddon matrix to unintentional motor vehicle collisions has been well-described. ${ }^{21,22}$ In a typical application, the host is the human occupant or pedestrian at risk of injury, the agent is the energy transmitted through the motor vehicle, the physical environment includes such elements as the street, weather, and lighting, and the social environment includes social and legal norms and practices, ranging from social tolerance of alcohol use to speed limit laws. Recently, the Haddon matrix also has been applied to selected public health emergencies, disasters, and mass-casualty incidents, but without the benefit of the aforementioned model of disaster risk. ${ }^{22-24}$

The Appendix shows how the Haddon matrix may be combined with the conceptual model of disaster risk to create a matrix of risk factors for each component risk. In this application, each risk has a before, during, and after phase, which in turn may be analyzed from the perspective of its human, material, physical environmental, and social environmental factors. The net result is a modified Haddon matrix applied across the hazard-health disaster continuum, producing what is essentially a three-dimensional taxonomy for the risk factors that contribute to a health disaster.

Since these risk factors vary somewhat from those in the original Haddon matrix, they merit some explanation. Human factors relate to the humans who create the hazard, humans who bring about the event (release energy), humans who are at risk for health damage, and humans who carry out the health response (emergency response). Human factors include the individual motivations, behaviors, knowledge, and competencies of these people across the hazard-health disaster continuum.

Material factors relate to the materials that comprise the hazard (stored energy), materials that affect energy release from the hazard, materials that affect health damage, and materials that affect health response. Material factors include the quality and quantity of materials, their design and construction, as well as their basic biological, chemical, and physical properties across the hazard-disaster continu- 
um.

Physical environmental factors relate to the setting of the hazard production, event occurrence (energy release), health damage, and health response. Physical environmental factors include the location, geography, terrain, climate, temperature, and lighting of each environment. In some disasters, the physical environment may be similar across each risk in the hazard-disaster continuum.

Social environmental factors also relate to hazard production, event occurrence, health damage, and health response. Social environmental factors include the ideology (cultural, religious and political belief systems), values, mores, funding, systems, organization, information, laws, and regulations that affect each risk. Social environmental factors usually are considered to be the most important group of risk factors, since they often are the most amenable to reduction by governmental and non-governmental organizations.

Not every component risk in the hazard-disaster continuum has every type of risk factor. For example, if we consider an earthquake-related health disaster, the underlying hazard-the earthquake fault-lacks a human dimension. Nevertheless, the risk of the event (i.e., earthquake) may include the human factor of underground nuclear testing and the risk of health damage may include multiple human risk factors related to the construction, location, and habitation of vulnerable structures.

It also is apparent that myriad factors-some simple, many complex - contributed to the terrible incident in London. One way by which we can begin to identify, sort, and categorize these risk factors is to apply this modified Haddon matrix to each component risk. In this manner, we may begin to unravel and understand the Gordian knot of human, material, physical environmental, and social environmental factors that underlie this tragedy. We may also identify hazards, terrorists, and strategies that pose risk and locations, times, and populations that are at risk for similar tragedies. Furthermore, we discover lessons that may help us prevent hazards, modify events, mitigate health damage, and optimize health response.

Such an analysis not only is likely to be relevant to London, but also is likely to have international bearing. For example, if it is nearly impossible to extinguish the violent belief system (Islamic fundamentalism) of the terrorists responsible for the London bombing (and innumerable others in recent years), what other measures may be taken to prevent the construction of future IEDs, modify or prevent their detonation, mitigate the resulting health damage, and provide an adequate health response? Those of us in the world of disaster medicine and health emergency management ask such questions every day. Thanks to the Haddon matrix, we have a tool that may lead us one step closer to finding the answers.

\section{References}

1. Cable News Network. NYPD gives details of July 07 bombs. In: Cable News Network, 04 August 2005. Available at www.lexis-nexis.com/universe. Accessed 10 August 2005.

2. Sherwood B: Forensic experts seek clues to terror mastermind. In: Financial Times (London, England), 08 August 2005. Available at www.lexis-nexis.com/universe. Accessed 10 August 2005.

3. Steele J: A month that changed the face of Britain. In: The Daily Telegraph (London), 01 August 2005. Available at www.lexisnexis.com/universe. Accessed 10 August 2005.

4. Agence France Presse: Facts about the London bombings, Britain's worst terror attack. In: Agence France Presse, 17 July 2005. Available at www.lexis-nexis.com/universe. Accessed 10 August 2005.

5. Sciolino E, Van Natta Jr D: Plastic vessels may link two sets of London bombings. In: The New York Times, 27 July 2005. Available at www.lcxisnexis.com/universe. Accessed 10 August 2005.

6. Ryan J, Montgomery $\mathrm{H}$ : Terrorism and medical response. NEnglJ Med 2005;353:543-545.

7. Chen AWY: The London bombings: A hospital doctor's experience. BMJ 2005;331:166.

8. Holden PJP: Improvising in an emergency. $N$ Engl J Med 2005;353: 541-543.

9. Wessely S: Victimhood and resilience. NEngl J Med 2005;353:548-550.

10. Redhead J, Ward P, Batrick N: Prehospital and hospital care. N Engl J Med 2005;353:546-547.

11. Mayor of London visits the Royal London Hospital to thank staff. In: Barts and the London NHS Trust Web site. Available at www.bartsandthelondon.org.uk/news/story.asp?id=810. Accessed 10 August 2005.

12. Law firm thanks emergency team. In: Royal Free Hampstead NHS Trust Web site. Available at www.royalfree.org.uk. Accessed 10 August 2005.

13. Prime Minister Tony Blair visits University College Hospital. In University College London Hospitals NHS Trust website. Available at http://www.uclh.org/news/pr_25_07_05_Tony_Blair_visit.shtml. Accessed 10 August 2005.

14. Sciolino E, Natta DN Jr: June report led Britain to lower its terror alert. In: The New York Times, 18 July 2005. Available at www.lexis.nexis.com/universe. Accessed 10 August 2005.

15. Calvert J, Leppard D: Police shot wrong man. In: The Sunday Times Britain, 24 July 2005. Available at www.timesonline.co.uk/article/0,20871706793,00.html. Accessed 10 August 2005.

16. TFQCDM, Sundnes KO, Birnbaum ML (eds): Health Disaster Management: Guidelines for Evaluation and Research in the Utstein Style. 1st ed. Madison, Wisconsin: Prehosp Disast Med, 1003, pp 1-177.

17. Arnold JL. Risk and risk assessment in health emergency management Prebosp Disast Med 2005;20:143-154.

18. Haddon W: A logical framework for categorizing highway safety phenomena and activity. I Trauma 1972:12:193-207.

19. Haddon W: Perspective on a current public health controversy. Am J Public Health 1975;65:1342-1344.

20. Haddon $W$ : Advances in the epidemiology of injuries as a basis for public policy. Public Health Rep 1980;95:411-421.

21. Runyan CW: Introduction: Back to the future-Revisiting Haddon's conceptualization of injury epidemiology and prevention. Epidemiol Rev 2003;25:60-64.

22. Peek-Asa C, Zwerling C: Role of environmental interventions in injury control and prevention. Epidemiol Rev 2003;25:77-89.

23. Albertsson $P$, Björnstig U, Falkmer T: The Haddon matrix, a tool for investigating severe bus and coach crashes. International Journal of Disaster Medicine 2003;1:109-119.

24. Barnett DJ, Balicer RD, Blodgett D, et al: The application of the Haddon matrix to public health readiness and response planning. Environ Health Perspect 2005;113:561-566. 
Appendix-Modified Haddon matrix for the risk of a disaster

\begin{tabular}{|c|c|c|c|c|c|}
\hline Risk & Phase & Human & Material & Physical environment & Social environment \\
\hline \multirow{3}{*}{ Hazard } & $\begin{array}{c}\text { Pre- } \\
\text { hazard }\end{array}$ & $\begin{array}{l}\text { Any human factor } \\
\text { affecting hazard } \\
\text { pre-production }\end{array}$ & $\begin{array}{l}\text { Any material factor } \\
\text { affecting hazard } \\
\text { pre-production }\end{array}$ & $\begin{array}{l}\text { Any physical } \\
\text { environmental factor } \\
\text { affecting hazard } \\
\text { pre-production }\end{array}$ & $\begin{array}{l}\text { Any social environmental } \\
\text { factor affecting hazard } \\
\text { pre-production }\end{array}$ \\
\hline & Hazard & $\begin{array}{l}\text { Any human factor } \\
\text { affecting hazard } \\
\text { production }\end{array}$ & $\begin{array}{l}\text { Any material factor } \\
\text { affecting hazard } \\
\text { production }\end{array}$ & $\begin{array}{l}\text { Any physical } \\
\text { environmental factor } \\
\text { affecting hazard } \\
\text { production }\end{array}$ & $\begin{array}{l}\text { Any social environmental } \\
\text { factor affecting hazard } \\
\text { production }\end{array}$ \\
\hline & $\begin{array}{l}\text { Post- } \\
\text { hazard }\end{array}$ & $\begin{array}{l}\text { Any human factor } \\
\text { affecting hazard } \\
\text { maintenance }\end{array}$ & $\begin{array}{l}\text { Any material factor } \\
\text { affecting hazard } \\
\text { maintenance }\end{array}$ & $\begin{array}{l}\text { Any physical } \\
\text { environmental factor } \\
\text { affecting hazard }\end{array}$ & $\begin{array}{l}\text { Any social environmental } \\
\text { factor affecting hazard } \\
\text { maintenance }\end{array}$ \\
\hline \multirow{3}{*}{ Event } & $\begin{array}{l}\text { Pre- } \\
\text { event }\end{array}$ & $\begin{array}{l}\text { Any human factor } \\
\text { affecting hazard } \\
\text { delivery }\end{array}$ & $\begin{array}{l}\text { Any material factor } \\
\text { affecting hazard } \\
\text { delivery }\end{array}$ & $\begin{array}{l}\text { Any physical } \\
\text { environmental factor } \\
\text { affecting hazard } \\
\text { delivery }\end{array}$ & $\begin{array}{l}\text { Any social environmental } \\
\text { factor affecting hazard } \\
\text { delivery }\end{array}$ \\
\hline & Event & $\begin{array}{l}\text { Any human factor } \\
\text { affecting energy } \\
\text { release from the } \\
\text { hazard }\end{array}$ & $\begin{array}{l}\text { Any material factor } \\
\text { affecting energy } \\
\text { release from the } \\
\text { hazard }\end{array}$ & $\begin{array}{l}\text { Any physical } \\
\text { environmental factor } \\
\text { affecting energy } \\
\text { release from the } \\
\text { hazard }\end{array}$ & $\begin{array}{l}\text { Any social environmental } \\
\text { factor affecting the } \\
\text { energy release from } \\
\text { the hazard }\end{array}$ \\
\hline & $\begin{array}{l}\text { Post- } \\
\text { event }\end{array}$ & $\begin{array}{l}\text { Any human factor } \\
\text { affecting energy } \\
\text { propagation }\end{array}$ & $\begin{array}{l}\text { Any material factor } \\
\text { affecting energy } \\
\text { propagation }\end{array}$ & $\begin{array}{l}\text { Any physical } \\
\text { environmental factor } \\
\text { affecting energy } \\
\text { propagation }\end{array}$ & $\begin{array}{l}\text { Any social environmental } \\
\text { factor affecting energy } \\
\text { propagation }\end{array}$ \\
\hline \multirow{3}{*}{$\begin{array}{c}\text { Health } \\
\text { damage }\end{array}$} & $\begin{array}{c}\text { Pre- } \\
\text { damage }\end{array}$ & $\begin{array}{l}\text { Any human factor } \\
\text { affecting exposure to } \\
\text { the energy release }\end{array}$ & $\begin{array}{l}\text { Any material factor } \\
\text { affecting exposure to } \\
\text { the energy release }\end{array}$ & $\begin{array}{l}\text { Any physical } \\
\text { environmental factor } \\
\text { affecting exposure to } \\
\text { the energy release }\end{array}$ & $\begin{array}{l}\text { Any social environmental } \\
\text { factor affecting } \\
\text { exposure to the energy } \\
\text { release }\end{array}$ \\
\hline & Damage & $\begin{array}{l}\text { Any human factor } \\
\text { affecting damage from } \\
\text { the energy release }\end{array}$ & $\begin{array}{l}\text { Any material factor } \\
\text { affecting damage from } \\
\text { the energy release }\end{array}$ & $\begin{array}{l}\text { Any physical } \\
\text { environmental factor } \\
\text { affecting damage from } \\
\text { the energy release }\end{array}$ & $\begin{array}{l}\text { Any social environmental } \\
\text { factor affecting damage } \\
\text { from the energy } \\
\text { release }\end{array}$ \\
\hline & $\begin{array}{c}\text { Post- } \\
\text { damage }\end{array}$ & $\begin{array}{l}\text { Any human factor } \\
\text { affecting damage } \\
\text { propagation }\end{array}$ & $\begin{array}{l}\text { Any material factor } \\
\text { affecting damage } \\
\text { propagation }\end{array}$ & $\begin{array}{l}\text { Any physical } \\
\text { environmental factor } \\
\text { affecting damage } \\
\text { propagation }\end{array}$ & $\begin{array}{l}\text { Any social environmental } \\
\text { factor affecting damage } \\
\text { propagation }\end{array}$ \\
\hline \multirow{3}{*}{$\begin{array}{l}\text { Inadequate } \\
\text { health } \\
\text { response }\end{array}$} & $\begin{array}{c}\text { Pre- } \\
\text { response }\end{array}$ & $\begin{array}{l}\text { Any human factor } \\
\text { affecting planning/ } \\
\text { preparedness for the } \\
\text { health damage }\end{array}$ & $\begin{array}{l}\text { Any material factor } \\
\text { affecting planning/ } \\
\text { preparedness for the } \\
\text { health damage }\end{array}$ & $\begin{array}{l}\text { Any physical } \\
\text { environmental factor } \\
\text { affecting planning/ } \\
\text { preparedness for the } \\
\text { health damage }\end{array}$ & $\begin{array}{l}\text { Any social environmental } \\
\text { factor affecting } \\
\text { planning/preparedness } \\
\text { for the health damage }\end{array}$ \\
\hline & Response & $\begin{array}{l}\text { Any human factor } \\
\text { affecting response to } \\
\text { the health damage }\end{array}$ & $\begin{array}{l}\text { Any material factor } \\
\text { affecting response to } \\
\text { the health damage }\end{array}$ & $\begin{array}{l}\text { Any physical } \\
\text { environmental factor } \\
\text { affecting response to } \\
\text { the health damage }\end{array}$ & $\begin{array}{l}\text { Any social environmental } \\
\text { factor affecting } \\
\text { response to the health } \\
\text { damage }\end{array}$ \\
\hline & $\begin{array}{c}\text { Post- } \\
\text { response }\end{array}$ & $\begin{array}{l}\text { Any human factor } \\
\text { affecting recovery from } \\
\text { the health damage }\end{array}$ & $\begin{array}{l}\text { Any material factor } \\
\text { affecting recovery from } \\
\text { the health damage }\end{array}$ & $\begin{array}{l}\text { Any physical } \\
\text { environmental factor } \\
\text { affecting recovery from } \\
\text { the health damage }\end{array}$ & $\begin{array}{l}\text { Any social environmental } \\
\text { factor affecting } \\
\text { recovery from the } \\
\text { health damage }\end{array}$ \\
\hline
\end{tabular}

